Revista Eletrônica de Direito Processual - REDP.

Rio de Janeiro. Ano 11. Volume 18. Número 2. Maio a Agosto de 2017

Periódico Quadrimestral da Pós-Graduação Stricto Sensu em Direito Processual da UERJ

Patrono: José Carlos Barbosa Moreira. ISSN 1982-7636. pp. 116-135

www.redp.uerj.br

\title{
A AGONIA DE UM PROCESSO: A IDEOLOGIA PROCESSUAL E A EXPECTATIVA DO NOVO CPC ${ }^{1}$
}

\section{THE AGONY OF A PROCESS: THE PROCESSUAL IDEOLOGY AND THE EXPECTATION OF THE NEW CPC}

\author{
"Homem, não sejas \\ Pássaro nostálgico, \\ Cão ou boi servil. \\ Levanta o fuzil \\ Contra o outro homem \\ Que te quer escravo. \\ Só depois disso morre" \\ José Paulo Paes - Baladilha
}

Emerson Ademir Borges de Oliveira Mestre e Doutor em Direito do Estado pela Universidade de São Paulo. Pós-Doutor em Democracia e Direitos Humanos pela Universidade de Coimbra. Professor da Universidade de Marília. Advogado. emersonboliveira@yahoo.com.br

RESUMO: A compreensão acerca de um processo civil com viés constitucional perpassa pela crítica aos fundamentos ideológicos que direcionaram o mesmo dentro do Estado Liberal e que se colocam como obstáculos para uma mudança de paradigma e de posicionamento acerca de novos institutos que buscam dar efetividade e celeridade ao processo, nos moldes do nosso Estado Contemporâneo. Hoje vemos que o processo que tanto estigmatiza e agoniza seus atores não o faz simplesmente pelas previsões legais, mas pelo receio e pelas posições

\footnotetext{
${ }^{1}$ Artigo recebido em 24/05/2017 e aprovado em 27/06/2017.
} 
Revista Eletrônica de Direito Processual - REDP.

Rio de Janeiro. Ano 11. Volume 18. Número 2. Maio a Agosto de 2017

Periódico Quadrimestral da Pós-Graduação Stricto Sensu em Direito Processual da UERJ

Patrono: José Carlos Barbosa Moreira. ISSN 1982-7636. pp. 116-135

www.redp.uerj.br

antepostas que impedem a evolução da mentalidade dos operadores judiciais. Logo, o que se se assiste e questiona é se serão os novos institutos do Código de Processo Civil suficientes para uma mudança dogmática ou a melhor das leis será insuficiente em face da recalcitrância dos agentes. O método de trabalho é dedutivo e a pesquisa eminentemente bibliográfica.

PALAVRAS-CHAVE: Novo Código de Processo Civil. Ideologia liberal. Igualdade material. Instrumentos de efetividade. Paradigma.

ABSTRACT: The understanding of a civil process with a constitutional bias runs through the criticism of the ideological foundations that directed the same within the Liberal State and that stand as obstacles to a paradigm shift and positioning about new institutes that seek to give effectiveness and celerity to the process, in the molds of our Contemporary State. Today we see that the process that stigmatizes and agonizes its actors does not do so simply by legal predictions, but by the fear and by the preposterous positions that impede the evolution of the mentality of the judicial operators. So what we are seeing and questioning is whether the new institutes of the Code of Civil Procedure will suffice for a dogmatic change or the best of laws will be insufficient in the face of the recalcitrance of the agents. The method of work is deductive and the research is eminently bibliographical.

KEYWORDS: New Code of Civil Procedure. Liberal ideology. Material equality. Instruments of effectiveness. Paradigm.

\section{INTRODUÇÃO: jurisdição, processo e garantias fundamentais}

Eis o processo o instrumento por meio do qual o Estado exerce a jurisdição com atendimento aos princípios e garantias fundamentais da Constituição Federal, conforme requer 
Revista Eletrônica de Direito Processual - REDP.

Rio de Janeiro. Ano 11. Volume 18. Número 2. Maio a Agosto de 2017

Periódico Quadrimestral da Pós-Graduação Stricto Sensu em Direito Processual da UERJ

Patrono: José Carlos Barbosa Moreira. ISSN 1982-7636. pp. 116-135

www.redp.uerj.br

o Estado Democrático ${ }^{2}$. Não se trata do processo em si ser constitucional, mas de intentar materializar o exercício da jurisdição dentro de um viés de direitos e garantias fundamentais. Noutras palavras: "a jurisdição realiza os seus fins através do processo"3. Mas não qualquer processo, e sim apenas aquele que se pauta pelos princípios constitucionais do processo.

Tenicamente, Enrico Tullio Liebman aponta o processo como uma "atividade mediante a qual se desempenha em concreto a função jurisdicional (...) através de uma série coordenada de atos que se sucedem no tempo e que tendem à formação de um ato final" ${ }^{\text {. }}$ Essas atividades coordenadas se dão através da ação conjunta e ética - princípio da cooperação - do órgão jurisdicional e das partes, todos estritamente necessários para o deslinde processual.

Pontes de Miranda, por outra via, ressalta o elemento homem no processo: "No sentido jurídico, nele há série de ações humana, que entre si se prendem, para se atingir determinado fim"5. Ou seja, o processo não tem forma e muito menos vida própria. Por pessoas é orientado e sobre essas mesmas (e outras) pessoas recairão suas consequências, boas ou danosas, em seu curso ou ao seu final. Assinalar que o processo é tão somente uma série coordenada de atos é mero jogo dogmático. E muito menos que é simples “operação"6.

Esse pensamento é corroborado pelo processualista baiano Calmon de Passos:

O processo, no âmbito jurídico, não é, portanto, algo que opera como simples meio, instrumento, sim um elemento que integra o próprio ser do Direito. A relação entre o chamado direito material e o processo não é uma relação meiolfim, instrumental, como se tem proclamado com tanta ênfase, ultimamente, por força do prestígio de seus arautos, sim uma relação integrativa, orgânica, substancial ${ }^{7}$.

\footnotetext{
2 MARINONI, Luiz Guilherme; ARENHART, Sérgio Cruz. Curso de processo civil. v.2. 6.ed. São Paulo: Revista dos Tribunais, 2007. p.54/55; MARINONI, Luiz Guilherme. Curso de processo civil. v.1. São Paulo: Revista dos Tribunais, 2006. p.404/405.

${ }^{3}$ MARINONI, Luiz Guilherme. Curso de processo civil. v.1. São Paulo: Revista dos Tribunais, 2006. p.451.

${ }^{4}$ LIEBMAN, Enrico Tullio. Manual de direito processual civil. v.1. p.33.

${ }^{5}$ MIRANDA, Pontes de. Tratado das ações. t.1. 2.ed. São Paulo: Revista dos Tribunais, 1972. p.287.

${ }^{6}$ SANTOS, Moacyr Amaral. Direito processual civil. v.1. 2.ed. São Paulo: Max Limonad, 1965. p.25.

${ }^{7}$ PASSOS, J. J. Calmon de. Direito, poder, justiça e processo. Rio de Janeiro: Forense, 1999. p.68.
} 
Revista Eletrônica de Direito Processual - REDP.

Rio de Janeiro. Ano 11. Volume 18. Número 2. Maio a Agosto de 2017

Periódico Quadrimestral da Pós-Graduação Stricto Sensu em Direito Processual da UERJ

Patrono: José Carlos Barbosa Moreira. ISSN 1982-7636. pp. 116-135

www.redp.uerj.br

O processo não é estático. Muito além disso, demonstra a sua dinamicidade nos seus efeitos sobre as partes, geralmente devastadores aos mais frágeis. Ser a parte mais débil em um processo é quase como uma sentença antecipada de morte, pois, ainda que ao final de saia vitorioso, muitos pedaços se perderão no caminho. Vale dizer, o processo sempre tem seu custo, material ou imaterial, mesmo para quem ganha.

Por essa razão, volta-se aos dizeres iniciais acerca das garantias fundamentais. Ora, se o processo está o tempo todo trabalhando com o elemento humano então é inegável que as garantias ao processo em verdade são as garantias aos desejos e manifestações humanas. Vale dizer, a igualdade não é meramente ao processo, mas às partes, tendo, contudo, sua ação na materialização da jurisdição: o processo.

Somente uma tutela adequada, efetiva e tempestiva pode se prestar àquele que busca através do processo a satisfação de seu direito material. Qualquer tutela que fuja a esses requisitos não poderá ser enquadrada dentro de um perfil constitucional da jurisdição. Qualquer tutela que não obedeça tais características é uma tutela não-humana, pelo menos para uma das partes.

Bem se sabe que o processo, por si só, ainda que, num exercício mental utópico, goze de todas as prerrogativas constitucionais e nivele equitativamente adversários economicamente distintos, já é um torpor. O processo é sempre agonia e ansiedade enquanto não tem seu trâmite finalizado. Estar em juízo esquarteja vagarosamente os litigantes, mas com muito mais eficácia o litigante mais frágil. Basta questionar àqueles que litigam nos Juízos de Família pelo Brasil afora.

Se o individuo entrou no processo lesado, dele o sairá ainda mais. Para essas pessoas, muitas vezes, perquirir em juízo o próprio direito é pior do que "esquecer" a lesão experimentada. A ineficácia do sistema jurisdicional induz à consciência da descrença no Judiciário. As portas dos fóruns reduzem os sujeitos a papel e o "arrependimento de ter direitos" é a principal sensação do ansioso cidadão ${ }^{8}$.

\footnotetext{
${ }^{8}$ Essa noção fica bastante delineada pelo litígio envolvendo o mercador e o judeu na Corta veneziana, na obra $O$ mercador de Veneza, de William Shakespeare.
} 


\section{O PROCESSO ENQUANTO INSTRUMENTO DE MANUTENÇÃO DE} DESIGUALDADE: ensaios de uma visão histórico-crítica do princípio da igualdade

A cada dia ficamos mais convencidos, por elementos histórico-críticos, pela análise cotidiana de espécies do objeto de investigação, pelo papel dos agentes do direito, ou até mesmo pela própria leitura fria do texto legislativo, de que a igualdade material é realmente o elemento imaginário assegurado em nossos princípios constitucionais. A eficácia de seu esconderijo corresponde também à sua importância, como o bulbo sob o cérebro.

Piero Calamandrei, em seus comentários aos aspectos psicológicos das medidas cautelares, assim se lança com, digamos, certa sobriedade: "Também nas causas, como na guerra, e por desgraça em toda eventualidade da vida, a parte rica, se encontra sempre em vantagem sobre a parte pobre",

Essa desigualdade, no entanto, parece-nos própria da condição humana. Uns nascem com mais e outros com menos condições. E sempre será assim, respeitando-se a individualidade humana que nos torna diferentes um do outro, tendo cada um suas peculiaridades, suas vicissitudes, seus medos, seus defeitos, suas propriedades, suas ambições, seus desejos, suas virtudes etc.

A ideologia liberalista, por sua vez, prefere, por seus interesses, que o homem seja visto formalmente como igual a outro homem.

Mostram-nos, igualmente, como o direito, na dinamicidade de sua experiência judicial, amoldou-se aos padrões da "ciência" moderna, ao pressupor a univocidade de sentido da lei, premissa legitimadora da extraordinária cadeia recursal que nos sufoca e da qual - como a ideologia do "pensamento único" neoliberal - não temos condições de nos libertar ${ }^{10}$.

\footnotetext{
${ }^{9}$ CALAMANDREI, Piero. Direito processual civil. v.3. Campinas: Bookseller, 1999. p.241.

${ }^{10}$ SILVA, Ovídio A. Baptista. Processo e ideologia. 2.ed. Rio de Janeiro: Forense, 2006. p.297.
} 
Revista Eletrônica de Direito Processual - REDP.

Rio de Janeiro. Ano 11. Volume 18. Número 2. Maio a Agosto de 2017

Periódico Quadrimestral da Pós-Graduação Stricto Sensu em Direito Processual da UERJ

Patrono: José Carlos Barbosa Moreira. ISSN 1982-7636. pp. 116-135

www.redp.uerj.br

Nesse sentido, a função do direito deixa de ser a de tratar os indivíduos de acordo com a sua desigualdade e passa a crê-los enquanto iguais, merecendo por essa razão o mesmo tratamento na tutela jurídica. De forma análoga opera o processo, sem se medir dessas individualidades e fazendo do mesmo um instrumento para a preponderância da injustiça ${ }^{11}$.

O processo não foi feito para alcançar a igualdade dos indivíduos. Não foi moldado para colocá-los em mesmo patamar na luta por seus direitos. E tem executado esse papel tão bem que devemos duvidar que mesmo por acidente colima com finalidade diferente. Desde que se têm indícios na história, ou mesmo desde as actiones romanas, o processo nunca deixou de revelar sua maligna face frente à parte mais fraca. Assim como o direito, nas salutares colocações engelistas e marxistas, nasceu para defender os mais fortes dos mais fracos, muito além da desigualdade material já perpetrada.

Nesse ponto, cumpre indicar o Rui Portanova: "Não basta a lei falar em igualdade dos cidadãos se estes não estão em condições de se servir, em igualdade de condições, daquele complexo e custoso instrumento de tutela dos direitos que é o processo" 12 .

O processo civil brasileiro, em sua especificidade, nos remete a tais conclusões a partir da prévia análise de sua estrutura. Traz o exemplo claro de Orwell, assimilando que “todos são iguais, mas uns mais iguais que os outros". Engana aos mais crentes na igualdade que se diz asseverar, mas faz notar aos mais cautos que acreditar na inverdade de tal compromisso é o "agir" para o mal. Devemos explicar: a conivência e a pacificação, aludidas da crença frágil, ajudam o sistema a moldar o seu processo da forma como lhe for mais conveniente, qual seja, massacrando os mais fracos na medida que traduz regalias aos poderosos.

Note-se, para os comuns o procedimento deveria ser o "comum", estampado no Livro I da Parte Especial do antigo CPC, pelo processo de conhecimento e cumprimento de

\footnotetext{
11 "Talvez ninguém atue de forma efetiva (em nível legislativo) contra a demora do processo porque esta muitas vezes beneficia os economicamente mais fortes: o que acontece na Justiça do Trabalho bem demonstra isto, pois muitas vezes o trabalhador é obrigado a abrir mão do seu direito, realizando acordos, apenas em razão da insuportável lentidão do processo trabalhista”. MARINONI, Luiz Guilherme. Observações a partir de uma visão da ideologia no processo civil. Revista jurídica da Faculdade de Direito de Curitiba, Curitiba, ano IX, n.7, p.135138, 1993. p.136.

${ }^{12}$ PORTANOVA, Rui. Motivações ideológicas da sentença. 5.ed. Porto Alegre: Livraria do Advogado, 2003. p.59.
} 
Revista Eletrônica de Direito Processual - REDP.

Rio de Janeiro. Ano 11. Volume 18. Número 2. Maio a Agosto de 2017

Periódico Quadrimestral da Pós-Graduação Stricto Sensu em Direito Processual da UERJ

Patrono: José Carlos Barbosa Moreira. ISSN 1982-7636. pp. 116-135

www.redp.uerj.br

sentença. Para os especiais, o procedimento era o do Livro III - "especial” (que não se engane pelo rito ordinário das ações petitórias, pois quem tem a propriedade terá a posse direta ou indireta). Àqueles roga a praga da desaceleração constante do processo, permitindo-lhes que seu direito só seja alcançado após delonga desmedida, isso para não dizer quando não lhe haver mais razão. A estes, por sua vez, garantia a liminar com a apresentação de rápidos quesitos, trazendo o bem da vida logo no início do processo, rogando à outra parte novamente a delonga processual distante do bem que lhe interessa.

De certo é que as reformas processuais civis de 1994 e 2005 foram sábias na busca por alternativas viáveis para dotar o processo de instrumental que equipare as partes. Entretanto, esbarra no mesmo problema que torna de difícil realização a persecução de qualquer bom objetivo que vise um direito mais justo: a concepção ideológica de nossos juristas!

Da mesma forma o novo Código de Processo Civil, dotado de uma visão completamente distinta do processo, com base, desde o artigo $1^{\circ}$, nos princípios constitucionais. O problema é questionar se os nossos juristas estão prontos para as habilidades que exigem o novo Código.

Mas no que diz respeito ao instituto da antecipação de tutela no antigo CPC e tutelas de urgência e evidência no novo, cada vez mais nos parece que há um certo receio dos juízes em dele fazer o uso para o qual foi disposto.

Para Luiz Guilherme Marinoni e Sérgio Cruz Arenhart, ainda quando a tutela antecipada aparecia como novidade processual, o

fato de a tutela antecipatória ser um instituto novo, e portanto ainda não muito bem conhecido, tem levado os juízes a uma certa timidez exagerada em seu uso. Entretanto, se todos sabem que o maior mal do processo é sua duração, e que esta sempre prejudica o autor que tem razão e beneficia, na mesma proporção, o réu que não a tem, não mais é possível que a tutela antecipatória continue a ser pensada de forma indevida, a menos que se pretenda que o autor continue a ser castigado e o réu beneficiado, ou, o que é pior, que se pretenda a fuga dos cidadãos da "justiça estatal". Nessa fuga, alguns privilegiados procurariam vias alternativas, enquanto outros 
Revista Eletrônica de Direito Processual - REDP.

Rio de Janeiro. Ano 11. Volume 18. Número 2. Maio a Agosto de 2017

Periódico Quadrimestral da Pós-Graduação Stricto Sensu em Direito Processual da UERJ

Patrono: José Carlos Barbosa Moreira. ISSN 1982-7636. pp. 116-135

www.redp.uerj.br

acabariam por ter de aceitar a lesão de seus direitos, sem nada poder fazer - o que é extremamente perigoso para a estabilidade social ${ }^{13}$.

A tutela antecipatória - de urgência ou de evidência - não cinge sua dificuldade tão somente ao pensamento de nossos juízes. Deve-se realizar que os requisitos que lhe traduzem em efetivação perfazem-se um tanto mais dificultosos do que o caso do procedimento especial, a partir do próprio texto legislativo. Parece que a tutela antecipatória nunca foi criada para ter o efeito da liminar especial. E, pelo que nos informa, parece difícil que venha a ter.

Veja-se, conforme artigos 561 e 562, aquele que tem a posse esbulhada, deve provar: a) ter a posse; b) o esbulho; c) data do esbulho; d) perda da posse. Na realidade, tratam-se de requisitos que, na prática, cabem dentro de uma única prova. Assim, uma foto ou uma reportagem de jornal já são suficientes para comprovar todos os requisitos, já que os mesmos decorrem de uma sequência lógica. Recebida a inicial, presente a prova dos requisitos, o juiz determinará a reintegração antes mesmo da manifestação do réu. Nota-se que o próprio Código impõe a antecipação.

Diferente é com o artigo 300, que trata da tutela provisória de urgência. São requisitos: a) probabilidade do direito; b) perigo de dano ou risco ao resultado útil do processo; c) possibilidade de se exigir caução; d) inexistência de perigo de irreversibilidade dos efeitos da decisão. São requisitos que, se considerados friamente, muitas vezes podem implicar no próprio indeferimento da pretensão. Só podem ser bem conduzidos por juristas igualmente conscientes do papel do processo civil.

Exemplifico. Se uma determinada pessoa pleiteia a concessão de uma prótese importada de um plano de saúde, que se limita a arcar com a nacional, em vista de laudo médico que ateste que o sucesso da cirurgia depende da importada, a concessão da tutela de urgência poderia esbarrar na irreversibilidade. É que, em se tratando de pessoa hipossuficiente, caso a decisão final venha a ser improcedente, nem se poderá desfazer a cirurgia, nem ao menos será possível obter o equivalente em dinheiro.

\footnotetext{
13 MARINONI, Luiz Guilherme; ARENHART, Sérgio Cruz. Curso de processo civil. v.2. 6.ed. São Paulo: Revista dos Tribunais, 2007. p.54/55; MARINONI, Luiz Guilherme. Curso de processo civil. v.1. São Paulo: Revista dos Tribunais, 2006. p.63.
} 
Revista Eletrônica de Direito Processual - REDP.

Rio de Janeiro. Ano 11. Volume 18. Número 2. Maio a Agosto de 2017

Periódico Quadrimestral da Pós-Graduação Stricto Sensu em Direito Processual da UERJ

Patrono: José Carlos Barbosa Moreira. ISSN 1982-7636. pp. 116-135

www.redp.uerj.br

Mas isso se o requisito for visualizado fora do âmbito da dignidade humana. A bem da verdade, a concessão de qualquer tutela provisória deveria estar baseada nos requisitos de razoabilidade e proporcionalidade. Mais nada.

Melhor explanando, o juiz deve colocar as partes na balança e visualizar primeiramente qual é a parte que pode suportar o ônus do processo, tendo contra si uma decisão que negue a tutela ou a conceda - divisão proporcional do ônus processual. Segundo, verificar se é razoável, a partir do direito que está em jogo, obrigar a outra parte a suportar tal ônus. Razoabilidade não se limita apenas ao aspecto financeiro, pois, como no exemplo acima, em caso de insucesso a parte não poderá arcar com os custos da prótese já implantada. A razoabilidade impõe uma análise sobre o sopesamento dos direitos, sendo certo que a dignidade da pessoa humana será sempre mais substancial do que qualquer quantia monetária.

É claro que isso não dispensa o lastro probatório mínimo, mas, como se vê, não a exigência de um direito certo - o que reservamos ao mandado de segurança -, mas de um direito crível, suficiente e que sirva como pressuposto para a análise acima.

Portanto, enquanto persistirem as insanas mentes inconformadas com o direito cotidianamente em mudanças, e enquanto a adequação legislativa não for feita por agentes responsáveis e conscientes de seu papel, a desigualdade material irá se perpetuar, invadindo todas as entranhas do processo, fazendo deste um instrumento para a manutenção do desequilíbrio entre as partes e a perpetuação da injustiça.

Felizmente, deve-se reconhecer, o novo Código tem gerado uma gradual evolução acerca da compreensão do processo civil e de sua importância para a tutela judicial. Mas ainda estamos engatinhando.

\section{O PROCESSO ENQUANTO INSTRUMENTO DE INEFETIVIDADE: a quem é “devido" o processo legal?}


Revista Eletrônica de Direito Processual - REDP.

Rio de Janeiro. Ano 11. Volume 18. Número 2. Maio a Agosto de 2017

Periódico Quadrimestral da Pós-Graduação Stricto Sensu em Direito Processual da UERJ

Patrono: José Carlos Barbosa Moreira. ISSN 1982-7636. pp. 116-135

www.redp.uerj.br

O Código de Processo Civil anterior passou por algumas importantes reformas no tocante à execução de títulos judiciais, rompendo com a antiga teoria dualista da satisfação, para torná-la mera continuidade do conhecimento. Os anos posteriores às mudanças colocaram à prova as mudanças de filosofia sobre o novo processo que nascia. Afinal, o título judicial não mais exigia novo processo, mas o cumprimento da sentença nos mesmos autos. Apesar disso, demandou certo tempo para que o Judiciário se acostumasse com as mudanças. Em muitos lugares, juízes autuavam o cumprimento de sentença em processo apenso. Tantas vezes, as mudanças não surtiram o efeito desejado. Não a princípio.

O novo Código sedimenta as mudanças e traz outras, como o fim do processo cautelar - mas não da tutela cautelar. As tutelas provisórias centram-se em torno da urgência e da evidência, com a possibilidade de estabilização da demanda e julgamento antecipado, conforme artigo $304, \S 1^{\circ}, \mathrm{CPC}$.

Evidente que cada alteração com o escopo de dar brevidade ao processo judicial e trazer equilíbrio entre as partes causa estranheza a princípio. O problema é que muitas vezes as desejáveis alterações não surtem efeito justamente por conta do receio em provocá-las e, principalmente, pela postura negativista em relação às novas formas constitucionais de se visualizar o processo.

Como por ora colocamos, não nos cabe prever o futuro. Não é função do estudioso do direito ser adivinho e tentar imaginar que talvez os juristas mal intencionados façam da lei, quiçá bem propositada, uma grande atabalhoadice.

Mas do que tem havido até então podemos falar.

Às partes que não eram beneficiadas pelo instituto de antecipação de tutela - e como eram poucas - só restava o amargo caminho do conhecimento em sua íntegra, culminando, no caso de vitória, pelas vias executivas.

Tudo isso acima que parece tão simples, a ponto de caber numa só frase, poderia tomar, em alguns casos, pasme-se, até mais de uma década, daquele que se vê privado de seu bem.

Ocorre que se a parte não puder convencer o juiz de que parece realmente ter sido destituído de seu bem, não lhe haveria alternativas se não "encarar" o processo de 
Revista Eletrônica de Direito Processual - REDP.

Rio de Janeiro. Ano 11. Volume 18. Número 2. Maio a Agosto de 2017

Periódico Quadrimestral da Pós-Graduação Stricto Sensu em Direito Processual da UERJ

Patrono: José Carlos Barbosa Moreira. ISSN 1982-7636. pp. 116-135

www.redp.uerj.br

conhecimento até o fim, com todas aquelas suas garantias duvidáveis de "cognição plena e exauriente", "ampla defesa", dentre outros sofismas.

Digo isso porque a verdade não nos parece possível de se alcançar, muito embora o mais perto dela possível devamos chegar. É uma obrigação. Fugir da verdade é uma desonestidade intelectual ${ }^{14}$. Ocorre que se passam longos anos procurando-se alcançar o inatingível. A verdade jamais será consequência da famigerada cognição plena e exauriente e o que se tem ao final nada mais é do que sua simples presunção, apenas um juízo de verossimilitude mais provável. O devido processo legal, por sua vez, estava se transformado em instrumento hábil na tentativa de retardar o curso do processo. Somente será "devido" àquele que assiste mais condições.

Pois bem.

Vencido o conhecimento e alcançada a confirmação por meio da manifestação da segunda instância por recursos do perdedor, tinha-se uma sentença tão somente condenatória. Um pedaço de papel que exprime uma vontade, mas que não é capaz de dar ao credor aquilo que tem direito. A condenação traduzia tão somente uma obrigação ${ }^{15}$. Era o momento do processo de execução, um antes novo processo, com nova citação, possibilidade de embargos etc. Isso se o crédito fosse líquido. Caso contrário a sentença deveria passar antes pelo processo de liquidação.

Essa discrepância processual obrigava o credor novamente a encarar o Judiciário, com vistas agora a alcançar efetivamente o bem pretendido. Dessa situação irrisória saíram frases que nos deveriam causar asco, como, por exemplo, "mais vale um péssimo acordo do que uma boa demanda" ou "o credor ganha, mas não leva"16. "Em outras palavras, a melhor forma de reivindicar um direito nem sempre é o processo" ${ }^{17}$.

\footnotetext{
14 “'A 'convicção da verdade' é relacionada com a limitação humana de buscar a verdade e, especialmente, com a correlação entre essa limitação e a necessidade de definição dos litígios. Para ser mais preciso: o juiz chega à convicção da verdade a partir da consciência da impossibilidade da descoberta da sua essência, uma vez que é essa que demonstra a falibilidade do processo para tanto". MARINONI, Luiz Guilherme. Prova convicção e justificativa diante da tutela antecipatória. Disponível em: 〈www.professormarinoni.com.br〉.

${ }^{15}$ Sobre o tema consultar: SILVA, Ovídio A. Baptista da. Processo e ideologia. 2.ed. Rio de Janeiro: Forense, 2006. cap. V.

${ }^{16}$ A prática protelatória tem se tornado tão comum e difundida que deixou de ser vista como uma "degeneração patológica" e passou-se a ser vista como "um refinado virtuosismo de boa prática forense". Noutras palavras, que
} 
Revista Eletrônica de Direito Processual - REDP.

Rio de Janeiro. Ano 11. Volume 18. Número 2. Maio a Agosto de 2017

Periódico Quadrimestral da Pós-Graduação Stricto Sensu em Direito Processual da UERJ

Patrono: José Carlos Barbosa Moreira. ISSN 1982-7636. pp. 116-135

www.redp.uerj.br

Conforme preleciona Calamandrei: "Em todo processo ocorre quase sempre que, frente à parte que tem pressa, está a que quer ir devagar: normalmente quem tem pressa é o autor, e quem não a tem é o demandado, interessado em alongar o mais que possa a rendição de contas" $" 18$.

Essa situação visou ser modificada pela Lei 11.232/2005, transformando a execução em parte do conhecimento, sendo-lhe nada mais do que efetivação de sua decisão. Também perdeu lugar os embargos do devedor, transformando-se em impugnação. E a referida liquidação de sentença não mais é processo apartado, perfazendo fase contínua do conhecimento. Mas demorou-se para que os juristas efetivamente trabalhassem não apenas com novas previsões legais, mas com uma nova mentalidade judicial.

Observe-se que o processo de antes tendia pela inefetividade do provimento, realmente cansando o autor do pleito. A demanda tornava-se dolorosa, quando não se pretendia nada além daquilo do qual se foi desprovido. Operava em sentido contrário aos dizeres de Rui Portanova: "Ao depois, a efetividade do processo tem olhos postos também na solução jurisdicional contenciosa. Busca decisões justas"19.

Mas não era só.

Antes já nos referimos ao instituto da antecipação de tutela, cujos elementos recaiam sobre o fundado receio de dano irreparável ou de difícil reparação e o manifesto protelatório do réu. A instituição da previsão do artigo 273 do CPC antigo visava já em 1994 combater com império a inefetividade do processo que lhe pudesse ser tristemente prejudicial, principalmente tendo-se em vista a perda da sua finalidade.

A antecipação de tutela através da entrega do bem ao autor propunha equilibrar as partes, buscando-se atingir a igualdade material. Mais do que isso, propunha desacreditar ao réu que lhe seria interessante protelar o andamento do feito, uma vez que o bem que antes

não as de Calamandrei, na página 235 de sua referida obra, o bom advogado passou a ser aquele que consegue "enrolar" a causa, permitindo ao réu que trabalhe com o bem que não é seu e ao final devolva tão somente aquilo que não lhe pertencia. CALAMANDREI, Piero. Direito processual civil. v.3. Campinas: Bookseller, 1999.

17 MARINONI, Luiz Guilherme. Observações a partir de uma visão da ideologia no processo civil. Revista jurídica da Faculdade de Direito de Curitiba, Curitiba, ano IX, n.7, p.135-138, 1993. p.138.

${ }^{18}$ CALAMANDREI, Piero. Direito processual civil. v.3. Campinas: Bookseller, 1999. p.234.

19 PORTANOVA, Rui. Motivações ideológicas da sentença. 5.ed. Porto Alegre: Livraria do Advogado, 2003. p.120. 
Revista Eletrônica de Direito Processual - REDP.

Rio de Janeiro. Ano 11. Volume 18. Número 2. Maio a Agosto de 2017

Periódico Quadrimestral da Pós-Graduação Stricto Sensu em Direito Processual da UERJ

Patrono: José Carlos Barbosa Moreira. ISSN 1982-7636. pp. 116-135

www.redp.uerj.br

guardava em mãos delas se esvaíram. Intentava destruir o famigerado dum pendet rendet (enquanto pende, rende) ${ }^{20}$. Todavia, suas dificuldades residiam sobre aquilo que já colocamos.

No entanto, tal problemática não deve escapar ilesa e sem solução. Luiz Guilherme

Marinoni aponta, inclusive, o principal responsável pela transformação do direito em efetivo:

A morosidade do processo, portanto, pode ser facilmente contornada pelo juiz cioso da sua responsabilidade ética e social, bastando ao mesmo admitir, em detrimento do princípio da nullla executio sinne titulo, que tanto fascínio sempre despertou nos processualistas, a liminar antecipatória no procedimento comum ${ }^{21}$.

Ora, acesso à Justiça, como propõem Cappelletti e Garth não se cinge tão somente em bater às portas do Poder Judiciário, mas receber a sua tutela efetiva, perceber do Judiciário aquilo que se tem direito em tempo hábil.

Da mesma forma, um novo Código é instrumento hábil para grandes conquistas, mas apenas se anteceder uma nova visão do processo pelos juristas.

\section{O AGRAVAMENTO DOS REFLEXOS PSICOLÓGICOS ÀS PARTES: o sofrimento decorrente da exagerada privação do bem da vida}

Certo é que o processo já é por sua própria natureza um torpor às partes. Sua próprio existência, no decorrer dos anos, é suficiente para desestabilizar emocionalmente as partes, principalmente por imaginar que a sentença poderá ser traduzida em efeitos que podem mudar completamente suas vidas, tanto para melhor, quanto para pior.

Muito embora o processo excessivamente rápido possa chegar a uma conclusão equivocada, o que se perfaz deveras vagaroso também produz sérios malefícios,

\footnotetext{
${ }^{20}$ CALAMANDREI, Piero. Direito processual civil. v.3. Campinas: Bookseller, 1999. p.233.

${ }^{21}$ MARINONI, Luiz Guilherme. Observações a partir de uma visão da ideologia no processo civil. Revista jurídica da Faculdade de Direito de Curitiba, Curitiba, ano IX, n.7, p.135-138, 1993. p.136.
} 
Revista Eletrônica de Direito Processual - REDP.

Rio de Janeiro. Ano 11. Volume 18. Número 2. Maio a Agosto de 2017

Periódico Quadrimestral da Pós-Graduação Stricto Sensu em Direito Processual da UERJ

Patrono: José Carlos Barbosa Moreira. ISSN 1982-7636. pp. 116-135

www.redp.uerj.br

principalmente quando acompanhado de alta carga de inefetividade danosa e ausência de equiparação no tratamento processual, características generalizadas do processo civil. É uma situação perversa por sua própria natureza que pode ficar ainda mais gravosa.

O efeito é tão devastador que se tem preferido as conciliações, altamente incentivadas pelo novo CPC, como coloca Rui Portanova: “o efeito psicológico e social de quem acorda voluntariamente o seu caso, faz da conciliação instituto adequado para alcançar a justiça" ${ }^{22}$. $\mathrm{O}$ problema é que as conciliações muitas vezes guardam resultados péssimos a uma das partes, mas que a prefere do que litigar.

Veja-se: não se afirma que a nova filosofia conciliadora esteja equivocada. É verdade que muito de sua causa seja o propósito de buscar maior satisfação às partes. Mas não se negue que sua causa seja também a morosidade judicial. A fim de evitar a postergação da solução judicial, as partes são incentivadas a buscar conciliação, inclusive com audiências obrigatórias no início do processo. Há uma certa nuvem que traduz a ideia de que ambos saem satisfeitos de um acordo. Esconde-se, todavia, a frustração de acreditar que é melhor perder um pouco - ou muito - do que lutar por um direito que se tem certeza existir.

E não há lirismo e nem grandeza nesse prolongado sofrimento, como apregoa Nietzche em sua "disciplina do sofrimento", responsável pela criação de todas as "sublimações do homem"23. O homem não cresce com a dor do processo. Esta somente o corrói, vagarosamente.

Laércio Becker, em excelente texto, discorre sobre a tortura exercida pelos próprios direitos humanos. Segundo ele o sadismo alimenta a própria busca da verdade, uma "esquizofrenia paranóide" dos juristas, enviando, enquanto faz rotulações claras (burocratização), o jurisdicionado para o abate ${ }^{24}$.

${ }^{22}$ PORTANOVA, Rui. Motivações ideológicas da sentença. 5.ed. Porto Alegre: Livraria do Advogado, 2003. p.120.

${ }^{23}$ NIETZSCHE, Friedrich. Para além do bem e do mal. São Paulo: Martin Claret, 2002. p.144.

24 "Mas falar em organização (e paranóia...) é falar em processo judicial, que, assim como os direitos humanos, é também um instrumento de legitimação da esfera estatal enquanto instância capaz de resolver os problemas das pessoas - quando na verdade o processo, ao não pôr à disposição das mesmas uma tutela jurisdicional adequada à demanda por direitos humanos além do processo penal (aparelho de repressão, o único que interessa ao Estado reforçar sob a bandeira dos 'direitos humanos'), praticamente nega sua própria instrumentalidade". BECKER, 
Revista Eletrônica de Direito Processual - REDP.

Rio de Janeiro. Ano 11. Volume 18. Número 2. Maio a Agosto de 2017

Periódico Quadrimestral da Pós-Graduação Stricto Sensu em Direito Processual da UERJ

Patrono: José Carlos Barbosa Moreira. ISSN 1982-7636. pp. 116-135

www.redp.uerj.br

Os hábeis transformam o processo em jogo e brincam com o psicológico da parte contrária durante todos os atos processuais. A dialética nada mais é do que mero instrumento para que aqueles consigam se sobrepujar à ignorância do lado contrário, amedrontando-o na mesma medida em que demonstram a habilidade e o vício que possuem durante a partida, fazendo muitas vezes com que o autor, certo de seu direito, passe a não ter mais tanta certeza assim.

Para Calamandrei, esse jogo de coação psicológica pode começar antes mesmo do início do processo, quando este é ainda mera ameaça. Trata-se da "guerra dos nervos, antes da dos papéis timbrados" 25 .

E continua:

Este emprego preventivo da coação psicológica compreende, na tática processual toda uma gama de matizes: começa pelo obrigado e discreto anúncio que todo advogado, antes de fazer uma intimação, dirige à parte contrária na esperança de evitar um litígio, e pode chegar, através de um crescendo de indiscrições e desfaçatezes, às formas de incorreção e de ilegitimidade que escorregam até a chantagem e a extorsão ${ }^{26}$.

Mas, uma vez iniciado o processo, doloroso por si só, poderá o hábil fazer uso de expedientes para lhe retardar o curso, não permitindo a efetividade do provimento e desequilibrando para seu lado a relação jurídica, ao passo que o juiz, se dizendo imparcial, posiciona-se do lado do mais forte.

A coação psicológica por aí não cessa. Imagine, ao exemplo de Piero Calamandrei, o advogado que espera até o último dia do prazo para promover sua apelação, não por sua própria negligência ou por esquecimento, mas para que dessa forma se espere chegar até o último dia, sob a ameaça do recurso suspensivo, a um acordo, geralmente péssimo para o autor do pleito $^{27}$.

Laércio. The Paine's Pain: Sade, Direitos Humanos e Processo. In: BECKER, L.A., SANTOS. E.L. Silva. Elementos para uma teoria crítica do processo. Porto Alegre: Sergio Antonio Fabris Editor, 2002. p.20.

${ }^{25}$ CALAMANDREI, Piero. Direito processual civil. v.3. Campinas: Bookseller, 1999. p.231.

${ }^{26}$ CALAMANDREI, Piero. Direito processual civil. v.3. Campinas: Bookseller, 1999. p.233.

${ }^{27}$ CALAMANDREI, Piero. Direito processual civil. v.3. Campinas: Bookseller, 1999. p.233. 
Revista Eletrônica de Direito Processual - REDP.

Rio de Janeiro. Ano 11. Volume 18. Número 2. Maio a Agosto de 2017

Periódico Quadrimestral da Pós-Graduação Stricto Sensu em Direito Processual da UERJ

Patrono: José Carlos Barbosa Moreira. ISSN 1982-7636. pp. 116-135

www.redp.uerj.br

Que falar das audiências e da oitiva de testemunhas, quando inquiridas sem a delicadeza necessária para a sua fragilidade psicológica, fazendo muitas vezes com que as mesmas desdigam o que anteriormente disseram ou que se confundam em sua exposição?

Esse é o jogo, não bastando que deles se conheça as regras, mas que se saiba jogar. $\mathrm{O}$ processo civil é uma celeuma na vida dos coitados que nele se aventuram por não possuírem outra alternativa. E quando chegam ao fim, cansados, desabam e confessam: "processo nunca mais". Assim cria-se e procria-se a descrença no Poder Judiciário.

Mas que não pensem os agentes do direito nada ter a ver com isso. Os juízes, principalmente, possuem papel preponderante na busca pela realização da justiça através do uso do direito, desconsiderando a habilidade que alguns advogados têm para o "jogo" do processo, vendo este através de um viés mais humanitário, tratando de pessoas, com sentimentos muito mais aflorados pela delonga processual, lembrando-se sempre dos dizeres de Geraldo Vandré, na canção "Disparada": "mas com gente é diferente".

\section{5. À GUISA DE CONCLUSÃO: o papel dos agentes do direito na minimização dos traumas}

Há culpa conjunta. Todos estamos vinculados ao sistema. Não se trata tão somente da doutrina, ou do entendimento dos juízes, da ação pecaminosa dos advogados, do mau intento das partes. Todos, sem exceção, são responsáveis pelo que hodiernamente se encontra perpetrado e consolidado, na mesma medida que também são os atores que deverão reverter esse quadro aprimorado pela história jurídica, ancorados em um novo diploma processual que muito promete, mas que será inútil sem a alternância de ideologia jurídica.

Alcançar as soluções pode não parecer tão simples. Mas é preciso se enveredar pelas trilhas da realidade factível.

Certo que a mudança legislativa antecede e abastece as previsões processuais-legais, mas é necessária uma hermenêutica mais humanista com uma visão mais digna de nossos agentes e uma constitucionalização das nossas leis processuais.

A propósito, lembra-nos Benjamin Cardozo: 
Revista Eletrônica de Direito Processual - REDP.

Rio de Janeiro. Ano 11. Volume 18. Número 2. Maio a Agosto de 2017

Periódico Quadrimestral da Pós-Graduação Stricto Sensu em Direito Processual da UERJ

Patrono: José Carlos Barbosa Moreira. ISSN 1982-7636. pp. 116-135

www.redp.uerj.br

Há injustiças e erros a serem mitigados, se não evitados. Muitas vezes se fala da interpretação como se ela não fosse nada, a não ser a procura e a descoberta de um sentido que, por mais obscuro e latente, tinha, não obstante, uma preexistência real e verificável na mente do legislador (...) O juiz, na condição de intérprete para a comunidade de seu sentido de lei e ordem, deve preencher omissões, corrigir incertezas e harmonizar resultados com justiça através de um método de livre decisão... Os tribunais devem "procurar luz entre os elementos sociais de todo tipo que são a força viva por trás dos fatos com que lidam" 28 .

Não nos escapa, por conseguinte, que a responsabilidade pesa mais sobre as costas dos magistrados, pois são eles que detêm o poder instituído. Podem negar os abusos por meio de uma interpretação mais equitativa do Código de Processo Civil e da aplicação dos princípios da Constituição Federal: "Mas, sobretudo, os meios indispensáveis com o fim de que o processo possa funcionar são os magistrados"29.

São eles que devem vincular a máquina estatal em prol do direito para se atingir a finalidade da justiça ${ }^{30}$. "Em suma, o juiz há de ter sempre os olhos postos na justiça que é o ‘objetivo síntese da jurisdição’ e comprometer-se com valores sociais e com suas próprias referências" $" 31$.

A mudança de atitude do juiz vem de fatores tanto internos quanto externos, como apontam os dizeres do filósofo Cardozo: "A história, o costume, a utilidade social, algum sentimento obrigatório de justiça ou às vezes talvez uma preocupação semi-intuitiva do espírito que permeia nossa lei, deve ir em socorro do ansioso juiz para dizer-lhe aonde ir..."32.

A valoração, partindo-se da gama de fatos que envolvem o magistrado desde seu nascimento, em especial pela sua criação e condição sócio-econômica, é especialmente

\footnotetext{
${ }^{28}$ In: MORRIS, Clarence (org.). Os grandes filósofos do direito. São Paulo: Martins Fontes, 2002. p.524-525.

${ }^{29}$ CALAMANDREI, Piero. Direito processual civil. v.3. Campinas: Bookseller, 1999. p.302.

30 "A terceira onda diz com o risco da burocratização do Poder Judiciário. Neste ponto vêm duas propostas. A primeira fala de uma atuação mais humana do julgador para acolher os consumidores pobres que agora acorrem ao Judiciário, bem como para protegê-los sem denegar justiça. Ao depois, fala na simplificação do procedimento e dos atos judiciais e do próprio direito substancial”. PORTANOVA, Rui. Motivações ideológicas da sentença. 5.ed. Porto Alegre: Livraria do Advogado, 2003. p.116.

${ }^{31}$ PORTANOVA, Rui. Motivações ideológicas da sentença. 5.ed. Porto Alegre: Livraria do Advogado, 2003. p.120.

${ }^{32}$ In: MORRIS, Clarence (org.). Os grandes filósofos do direito. São Paulo: Martins Fontes, 2002. p.528.
} 
Revista Eletrônica de Direito Processual - REDP.

Rio de Janeiro. Ano 11. Volume 18. Número 2. Maio a Agosto de 2017

Periódico Quadrimestral da Pós-Graduação Stricto Sensu em Direito Processual da UERJ

Patrono: José Carlos Barbosa Moreira. ISSN 1982-7636. pp. 116-135

www.redp.uerj.br

transformadora da concepção de direito que deverá ter. Eles lhe moldam a postura enquanto poder, agindo mesmo a partir da própria inconsciência do juiz. Alterar o quadro nunca é tarde. Nós estamos em constante transformação todos os dias de nossas vidas, jamais tomando o mesmo banho no mesmo rio. O nosso redor muda, assim como nós.

Da mesma forma, a ideologia que ilumina uma determinada legislação ou instituto não pode ser ignorada na feição dos seus operadores. $\mathrm{O}$ juiz trabalhista que mantém posição prévia pró-empresa, assim como aquele que atua no Juizado Especial, certamente não estão conscientes de seu papel social. Aquele que no Juizado Especial se vincula muito ao tecnicismo e olvida as dificuldades das pessoas físicas que ali litigam, muitas sem advogado, desdenham da filosofia que ergueu sua própria jurisdição.

Da mesma forma atuam aqueles que buscam no novo Código de Processo uma forma de institucionalizar as ideologias anteriores, aquelas mesmas que partiam do pressuposto de igualdade entre as partes e procedimentos.

Não se deve furtar, por outro lado, ao papel dos demais juristas na mudança de concepção processualística. Como os juízes, somos todos humanos, em constante mudança. Devemos nos guiar não pelo interesse mesquinho e pela vantagem, por vezes tão irrisória quanto estúpida, de que podemos arrancar de todas as situações. A má-fé processual, que leva ao manifesto protelatório, é uma dessas incoerências que advogados carregam consigo. Nela expõem tudo aquilo que odiariam que lhe fosse direcionado. A desonestidade - que nos lembra os dizeres de Rui Barbosa, na qual perfila sua preocupação com o dia em que teria vergonha de ser honesto - está arremessada sobre os tribunais, escritórios e processos. E quem perde? O mais fraco, é claro, que pagará o preço insuportável de não ver o seu dia, enfim, chegar.

Cumpre ressaltar que a cláusula geral de negociação do procedimento, estipulada pelo artigo 191 do novo CPC, pela qual juízes e partes podem fixar calendário para a prática dos atos processuais, inclusive para diminuir-lhes, na realidade homenageia o cooperativismo e a boa-fé entre todos os sujeitos do processo. Mais do que isso, ao colocar em prática os artigos $6^{\circ}, 7^{\circ}$ e $8^{\circ}$ do novo CPC, segundo os quais a cooperação de boa-fé deve ser justa e equilibrada, 
Revista Eletrônica de Direito Processual - REDP.

Rio de Janeiro. Ano 11. Volume 18. Número 2. Maio a Agosto de 2017

Periódico Quadrimestral da Pós-Graduação Stricto Sensu em Direito Processual da UERJ

Patrono: José Carlos Barbosa Moreira. ISSN 1982-7636. pp. 116-135

www.redp.uerj.br

busca-se a efetivação da dignidade humana, razoabilidade, proporcionalidade, dentre outros princípios.

Os professores e doutrinadores que insistem na visão estritamente dogmática do processo também se fazem irreais, não aceitando a concepção teleológica do procedimento. Assim, contribuem para a insegurança e a dúvida que se perpetua na concepção de alguém sempre que se tenha um direito, por mais nítido que seja. Contribuem para a ignorância, formando não agentes, mas burocratas do direito que atenuam sua própria responsabilidade por se assumirem na condição pífia de escravos da lei.

Estamos convencidos, entretanto, que um sem-número de agentes, conscientes de seu real papel na transformação do direito, têm ascendido com real respeito por parte até mesmo dos dogmáticos, contribuintes estes de uma ideologia aniquiladora do ideal de justiça. É de se ver que muitos destes têm se rendido aos encantos de uma visão humanitária do direito processual e que a contumácia negativista tem cedido lugar aos desígnios de um papel social mais correspondente com a prestação da tutela jurisdicional por parte do Estado em contrapartida à renúncia do cidadão de buscar a justiça pelas suas próprias mãos. Eis o que permitiu nascer um novo Código mais humanizado, embora ainda atrasado.

Mas um Código respeitável, com a institucionalização de questões nascentes e efetivas no Brasil. O sistema de precedentes, os processos coletivos e a limitação recursal, por exemplo, iluminam uma nova visão. Que de nada adiantará, no entanto, se a ideologia processualística se prender no tempo.

Para finalizar, sobrelevamos uma citação de Calamandrei: "o bom funcionamento da justiça depende dos homens e não das leis, e que o ótimo sistema judicial é aquele em que os juízes e os advogados, vinculados por recíproca confiança, procuram a solução de suas dúvidas, mais que na pesada doutrina, na viva e fresca humanidade"33.

Essa é a nossa luta, esses os nossos dilemas.

\footnotetext{
${ }^{33}$ CALAMANDREI, Piero. Direito processual civil. v.3. Campinas: Bookseller, 1999. p.217.
} 
Revista Eletrônica de Direito Processual - REDP.

Rio de Janeiro. Ano 11. Volume 18. Número 2. Maio a Agosto de 2017

Periódico Quadrimestral da Pós-Graduação Stricto Sensu em Direito Processual da UERJ

Patrono: José Carlos Barbosa Moreira. ISSN 1982-7636. pp. 116-135

www.redp.uerj.br

\section{REFERÊNCIAS BIBLIOGRÁFICAS:}

BECKER, L.A. The Paine's Pain: Sade, Direitos Humanos e Processo. In: BECKER, L.A., SANTOS. E.L. Silva. Elementos para uma teoria crítica do processo. Porto Alegre: Sergio Antonio Fabris Editor, 2002.

CALAMANDREI, Piero. Direito processual civil. Campinas: Bookseller, 1999. v.3.

CALMON DE PASSOS, José Joaquim. Direito, poder, justiça e processo: julgando os que nos julgam. Rio de Janeiro: Forense, 1999.

MARINONI, Luiz Guilherme. Observações a partir de uma visão da ideologia no processo civil. Revista jurídica da Faculdade de Direito de Curitiba, Curitiba, ano IX, n.7, p.135-138, 1993.

- Prova, convicção e justificativa diante da tutela antecipatória. Disponível em: <www.professormarinoni.com.br>. Acesso em: 20 ago. 2007.

. Curso de Processo Civil. v.1: Teoria geral do processo. 1.ed. São Paulo: Revista dos Tribunais, 2006.

MARINONI, Luiz Guilherme; ARENHART, Sérgio Cruz. Curso de Processo Civil. v.2: Processo de conhecimento. 6.ed. São Paulo: Revista dos Tribunais, 2007.

MORRIS, Clarence (org.). Os grandes filósofos do direito. 1.ed. São Paulo: Martins Fontes, 2002.

NIETZSCHE, Friedrich. Para além do bem e do mal. São Paulo: Martin Claret, 2002.

PONTES DE MIRANDA, Francisco Cavalcante. Tratado das ações. 2.ed. São Paulo: Revista dos Tribunais, 1972. t.I.

PORTANOVA, Rui. Motivações ideológicas da sentença. 5.ed. Porto Alegre: Livraria do Advogado, 2003.

SANTOS, Moacyr Amaral. Primeiras linhas de direito processual civil. 2.ed. São Paulo: Max Limonad, 1965. v.1.

SILVA, Ovídio A. Baptista. Processo e ideologia: o paradigma racionalista. 2.ed. Rio de Janeiro: Forense, 2006. 